\title{
Design of Monitoring Tool Heartbeat Rate and Human Body Temperature Based on WEB
}

\author{
Jalinas $^{1}$, Wahyu Kusuma Raharja ${ }^{2}$, and Bobby Putra Emas Wijaya ${ }^{2, *}$ \\ ${ }^{1}$ Department of Computer System, Gunadarma University, Jl. Margonda Raya No.100, Pondok Cina, \\ Beji, Kota Depok, Jawa Barat 16424 \\ ${ }^{2}$ Department of Electrical Engineering, Gunadarma University, Jl. Margonda Raya No.100, Pondok \\ Cina, Beji, Kota Depok, Jawa Barat 16424
}

\begin{abstract}
The heart is one of the most important organs in the human body. One way to know heart health is to measure the number of heart beats per minute and body temperature also shows health, many heart rate and body temperature devices but can only be accessed offline. This research aims to design a heart rate detector and human body temperature that the measurement results can be accessed via web pages anywhere and anytime. This device can be used by many users by entering different ID numbers. The design consists of input blocks: pulse sensor, DS18B20 sensor and 3x4 keypad button. Process blocks: Arduino Mega 2560 Microcontroller, Ethernet Shield, router and USB modem. And output block: 16x2 LCD and mobile phone or PC to access web page. Based on the test results, this tool successfully measures the heart rate with an average error percentage of $2.702 \%$ when compared with the oxymeter tool. On the measurement of body temperature get the result of the average error percentage of $2.18 \%$.
\end{abstract}

Key words: Heartbeat rate, temperature, WEB

\section{Introduction}

Health is a very important aspects in life, one of them is heart health. The heart is a vital organ in the human body who have a function to pump blood throughout the body. Pumping activity of the heart can be measured using equipment called an electrocardiograph or ECG. Many factors that makes heart are not working normally, one of which is temperature, body temperature or environment temperature, based on a journal written in [1]. In the study said by Waterman, which claimed that in environments with high temperature will increase the metabolism in the body, then will leads to increased respiration rate and also have an impact on increased heart rate [1].

Human body temperature also important aspects in human life, too warm human bodies have mean that our health was interfere. The earth's temperature continues to rise due to several factors such as the greenhouse effect that makes global warming. Increasingly hot environment temperature around us, one of our body will dehydration and lack of water, this can make an increase in body temperature because the body fails to cool its own body, hot

\footnotetext{
* Corresponding author: bobbyhoult@gmail.com
} 
temperatures also makes emotional unstable and heart health was impaired, as written by Ananya Mandal in his article in news-medical.net [2]. With these conditions, the authors created a tool to detect the human heart rate and body temperature, because in order to know whether at a certain temperature conditions a person's heartbeat is still in the normal range is $60 \mathrm{bpm}$ to $100 \mathrm{bpm}$ for adult (bpm = beats per minute).

Research has been carried by [3, 4], has made a heart rate monitoring devices. In that studies, a tool designed just for a heartbeat, and there is a WiFi communication to sent the result data but that communication there are to much weakness like limited distance because that things the authors created a tool that monitoring heart rate and body temperature with WEB or internet connection. Then creating a circuit which use a pulse sensor component as the detection of the heartbeat by placing one finger to the pulse sensor will be detected, the heart rate and blood volume is synchronous to the heart beat, this technique can be used to calculate the heart rate, and sensor DS18B20 as the temperature gauge body Because DS18B20 sensor accurate body temperature reading. This tool is certainly very useful, because we can check the state of the heart and body temperature anywhere, with pulse sensor and a temperature sensor which is accurate enough.

Rapid development of information technology, one that is internet technology. Internet is a technology that uses an electronic device to exchange data wirelessly with easy installation and cost, that the technology is in great demand by the public. Because of that the author wants to make the heartbeat detection device and the body temperature automatic calculation process works with the results displayed on a $16 \times 2$ LCD which also results can be accessed via the WEB with the internet on a PC or a smartphone with a internet connection, the author choose internet because it was very easy to use, and whoever can be access. When someone check them heart and temperature condition, the result can be seen leter because the result saved by internet and can be accessed.

\section{Literature Review}

\subsection{Heart rate}

Heart rate, or heart pulse, is the speed of the heartbeat measured by the number of poundings of the heart per unit of time, typically beats per minute (bpm). The heart rate can vary according to the body's physical needs, including the need to absorb oxygen and excrete carbon dioxide. Activities that can provoke change include physical exercise, sleep, anxiety, stress, illness, ingesting, and drugs. The resting heart rate of a newborn can be 120 bpm and this gradually decreases until maturity and then gradually increases again with age. The normal resting adult human heart rate ranges from $60 \mathrm{bpm}$ to $80 \mathrm{bpm}$. Bradycardia is a slow heart rate, defined as below $60 \mathrm{bpm}$. Tachycardia is a fast heart rate, defined as above $100 \mathrm{bpm}$ at rest. When the heart is not beating in a regular pattern, this is referred to as an arrhythmia. These abnormalities of heart rate sometimes indicate disease [5].

\subsection{Photoplethysmography (PPG)}

Photoelectric plethysmography, also known as photoplethysmography and its acronym in some literature, is (PTG/PPG) and when it is called digital volume pulse, the acronym is (DVP). PPG is easy to set up, convenient, simple and economically efficient. Moreover, it does not need direct contact with the skin surface. It uses a probe which contains a light source and a detector to detect cardio-vascular pulse wave that propagates through the body. The PPG signal reflects the blood movement in the vessel, which goes from the heart to the fingertips and toes through the blood vessels in a wave-like motion. It is an optical 
measurement technique that uses an invisible infrared light sent into the tissue and the amount of the backscattered light corresponds with the variation of the blood volume. The low-cost and simplicity of this optical based technology could offer significant benefits to healthcare (e.g. in primary care where non-invasive, accurate and simple-to-use diagnostic techniques are desirable). Further development of PPG could place this methodology among other tools used in the management of vascular disease [6].

\subsection{Body temperature}

Temperature is a magnitude that states the degree of cold or heat of an object and a tool used to measure the temperature is a thermometer. In daily life people measure temperature using the sense of touch. But with the development of technology that was created a thermometer to measure the temperature with a thermometer with valid result. First pioneered who making the thermometer is Galileo Galilei (1564-1642) at 1595. The tool is called the termoskop in the shaped of empty flask equipped with a long pipe with end of the pipe opened. At first, the air in the flask was heated so that it expands. End of the pipe that open is then dipped into a colorless liquid. When the air inside flask is shrinking, the liquid into the pipe, but not until the flask. That's how termoscop work. For different temperatures, a high column of liquid in the pipeline are also different. The height column is used to determine the temperature. The working principle of artificial Galileo thermometer based on changes in the volume of gas in the flask. But now the thermometer that often used are made of liquid mercury and alkhohol. The principle used is thermal expansion of liquids when an increase in temperature of the object [7].

\section{System Design}

\subsection{Detailed circuit design}

Figure 1 shows block diagram Monitoring Tool Heartbeat Rate and Human Body Temperature system design. There are three blocks were used that block pulse sensor [7], temperature sensor DS18B20 [8] and 3×4 keypad. The output of this sensor will go to block the process. Block process consists of three distinct blocks namely Arduino Mega 2560 Microcontroller block [9] and block Ethernet Shield TL-MR3020 router [10]. At the output blocks are also composed of three different blocks that block LCD Display, PC block, and block the smartphone. So pulse sensor and a temperature sensor results will be processed by a microcontroller Arduino Mega 2560 is then displayed on the LCD display, and can be displayed via the WEB on smartphones and PC but the result of a block of microcontroller Arduino Mega 2560 is passed to block the Ethernet Shield and then to the router. 


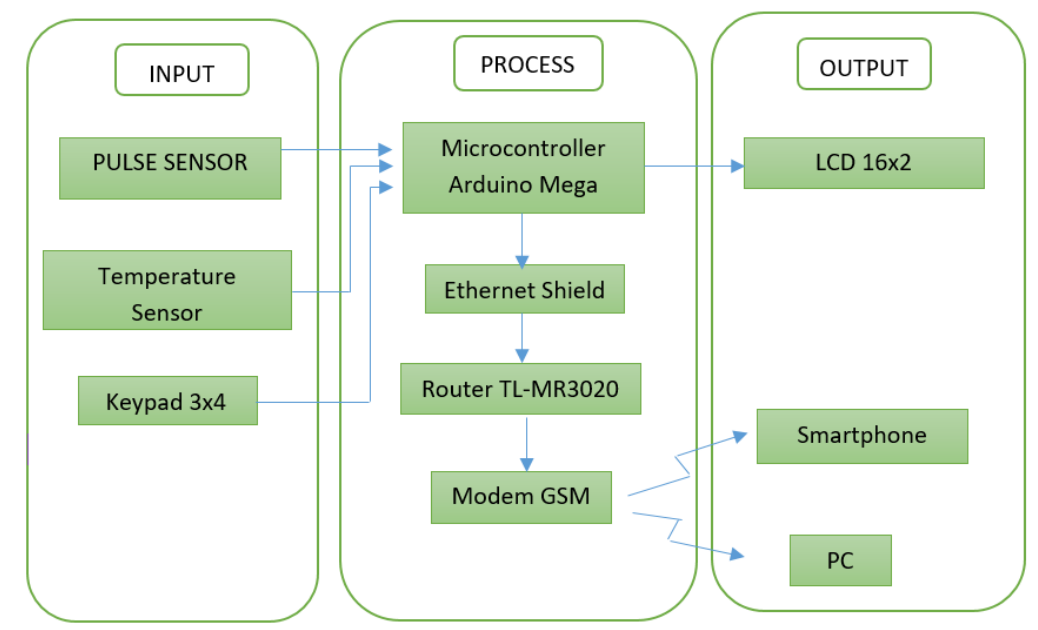

Fig. 1. Block diagram of monitoring tool heartbeat rate and human body temperature system design.

Figure 2 shows schematic of monitoring tool heartbeat rate and human body temperature. The circuit using a voltage of $5 \mathrm{~V}$ of Arduino Mega or ethernet, because in terms of the hardware installation of ethernet is take below the Arduino Mega, but used by ethernet Circuit below using a voltage of $5 \mathrm{~V}$ of Arduino Mega or ethernet, because in terms of the hardware installation of ethernet is below the Arduino Mega, but used by ethernet only four pins of arduino mega i.e. pin $50 \mathrm{MISO}$, pin $51 \mathrm{MOSI}$, pin $52 \mathrm{SCK}$, pin $53 \mathrm{ETH}$ CS, next to the LCD side.

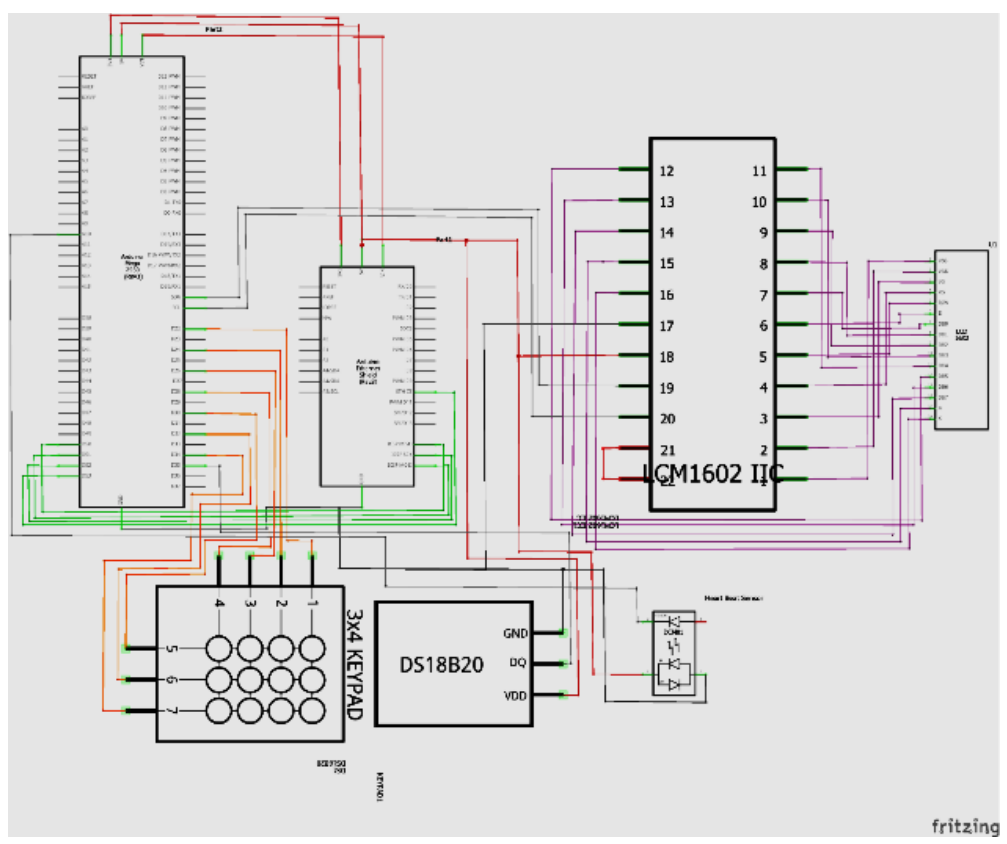

Fig. 2. Schematic of monitoring tool heartbeat rate and human body temperature . 
On the circuit using $16 \times 2$ LCD is connected to the I2C LCD so that the pins are used less, with explanations pin 1 to $16 \mathrm{LCD}$ connected to pins 1 to 16 on $\mathrm{I} 2 \mathrm{C}$, pin 1 connected to pin 1 following pin 2 connected with pin 2 and up to 16 pins, and the pins 21 and 22 on the $\mathrm{I} 2 \mathrm{C}$ on a direct dial aim to make the brightness on and pin $17 \mathrm{I} 2 \mathrm{C}$ connected to ground, pin 18 connected to VCC, pin 19 is connected to pin 20 arduino that the SDA and the pin 21 arduino which is connected to the SDL. Next to the keypad, the keypad using 7 pins connected to digital pin arduino mega namely digital pins 1 to 7 , pins 1 keypad is connected to the pin 22 follows the pin 2 connected to pin 24 and until 7 pin keypad. Then the temperature sensor DS18B20 on the circuit above using 3 pin them vcc, ground and data, VCC is connected to the voltage arduino $5 \mathrm{~V}$ following with the ground, then pin of data from the sensors connected to the pin 35 digital arduino, then to the heart beat sensor.

\subsection{Software design}

Software design shown in Figure 3, Figure 4, Figure 5 and Figure 6 describes a program that is used to operate the device. In this section consists of a flowchart and explain how the device works.

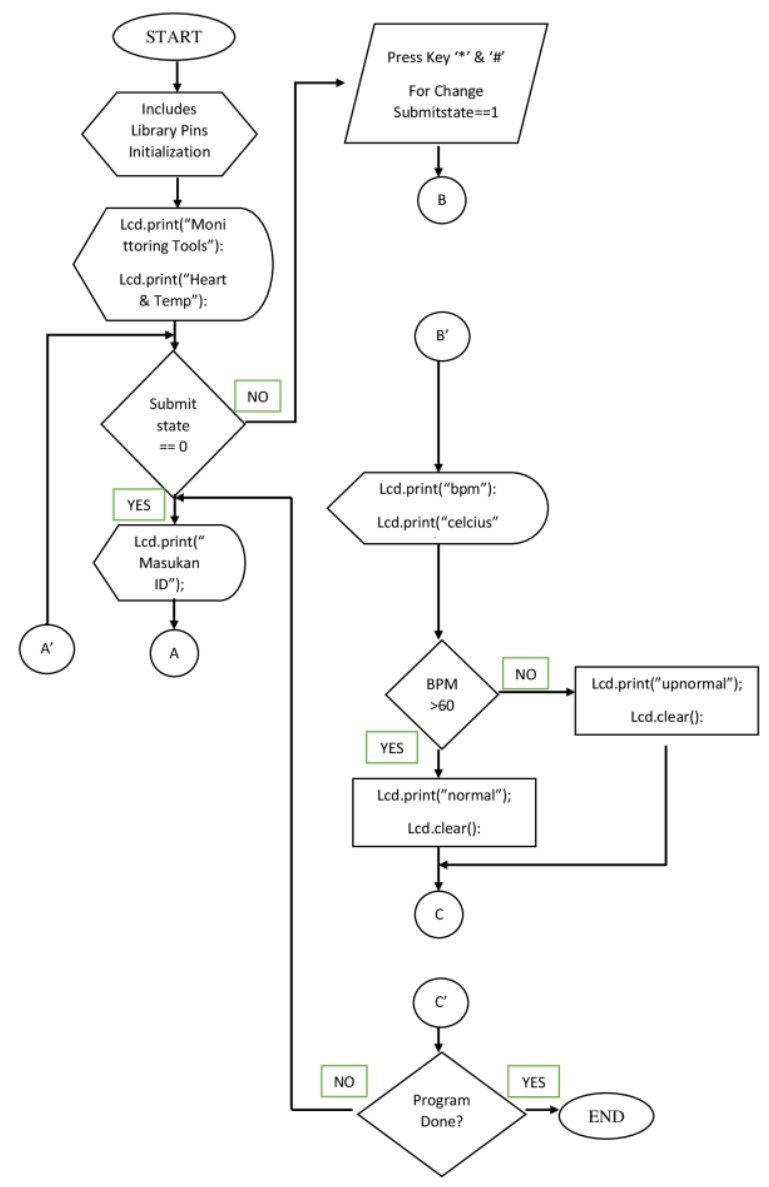

Fig. 3. System flowchart. 


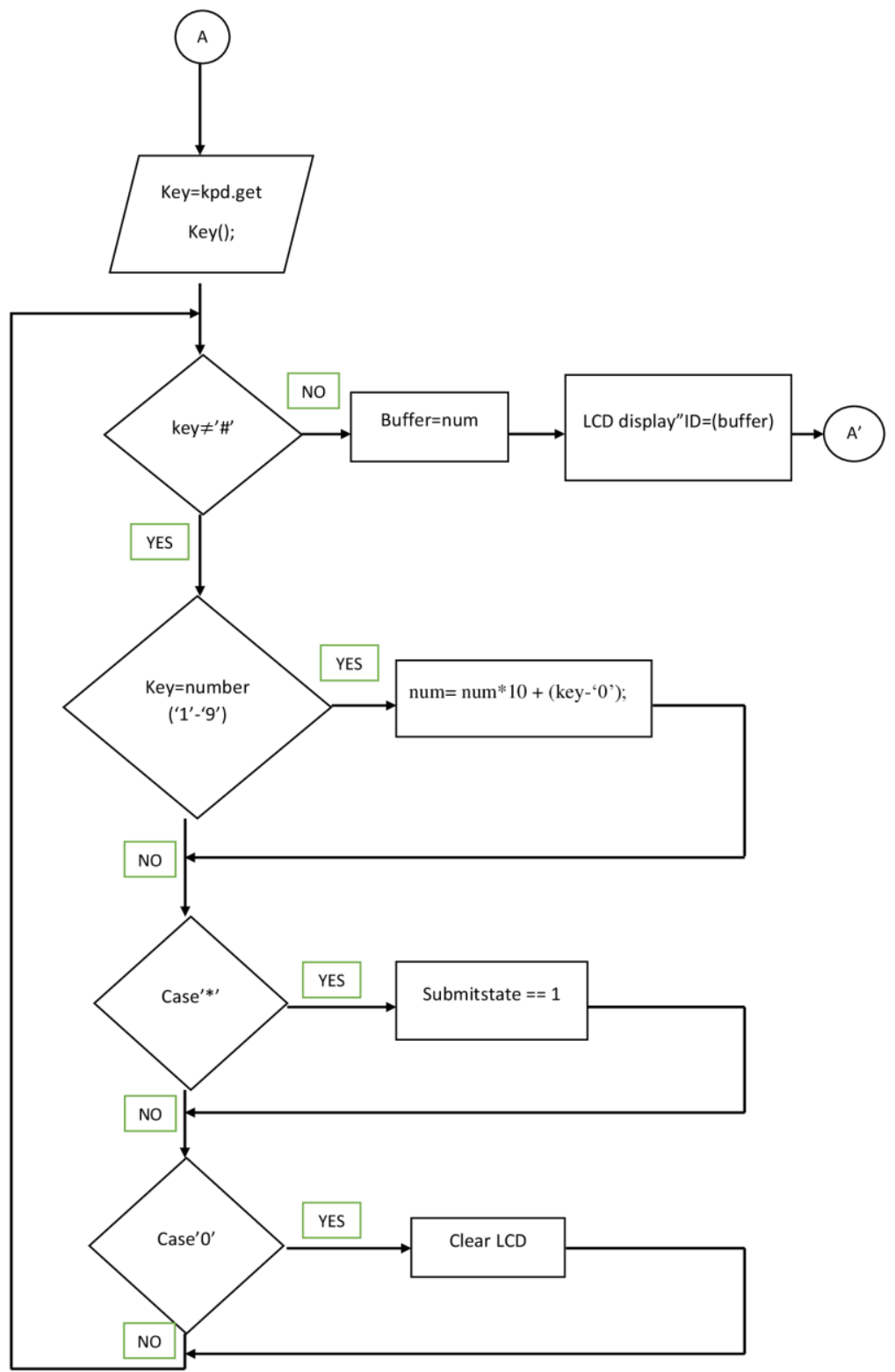

Fig. 4. Keypad system flowchart. 


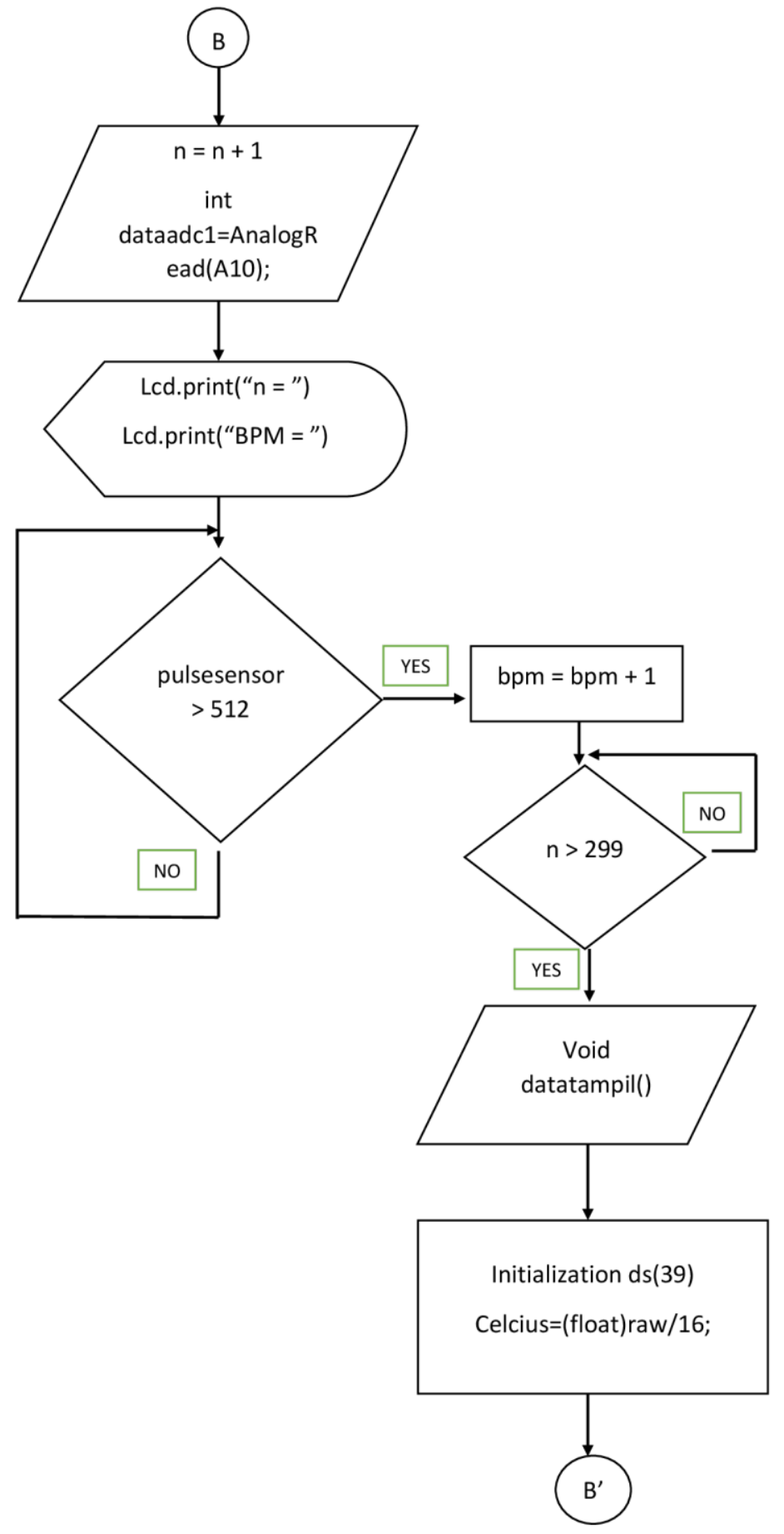

Fig. 5. Sensoring system flowchart. 


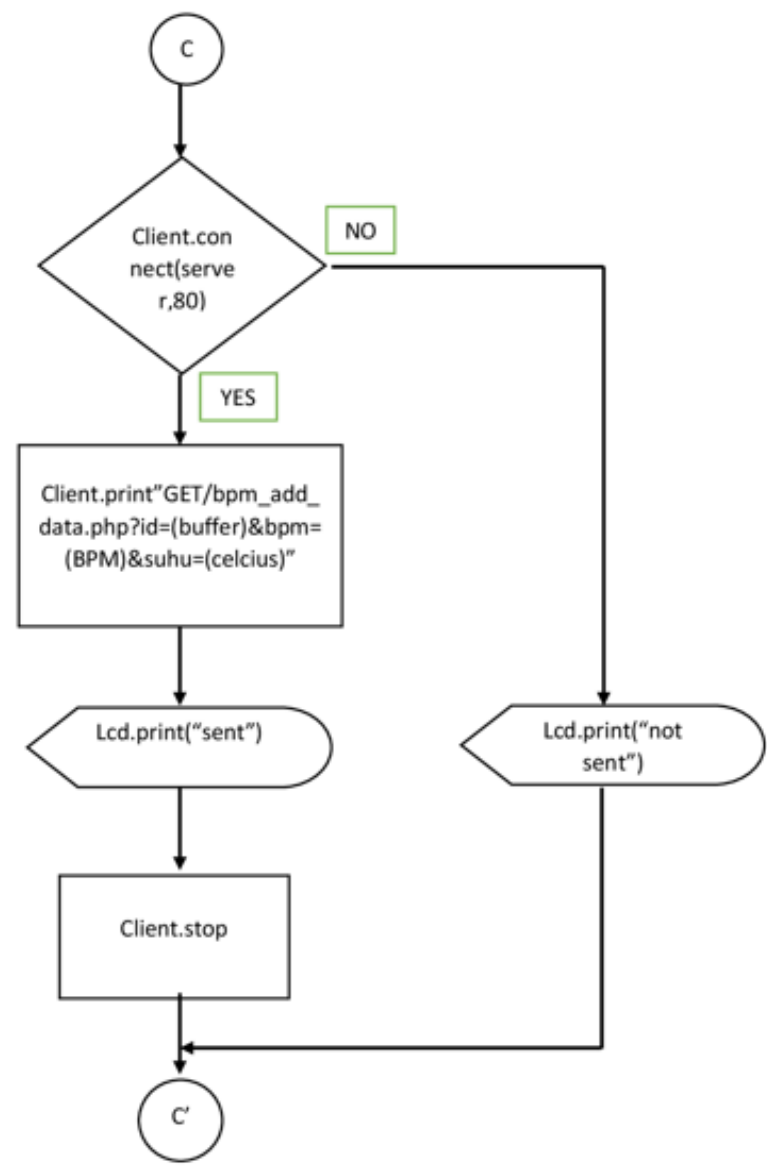

Fig. 6. Internet system flowchart.

\section{Device testing and analysis}

\subsection{Pulse sensor and DS18B20 testing}

Figure 7 shows the results from the heartbeat sensor output waveform of pulse sensor when it is not detected and detected.

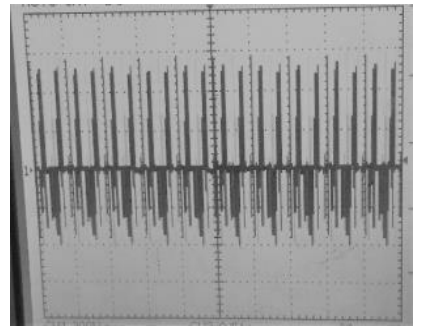

(a)

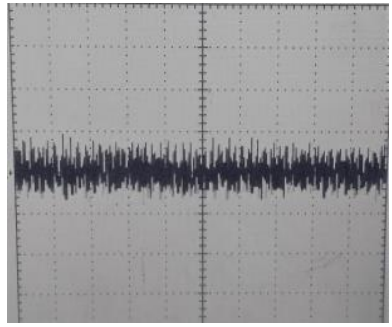

(b)

Fig. 7. (a) When sensor detected, (b) when sensor not detected. 
The image shown in Figure 8 result of body temperature sensor output waveform DS18B20

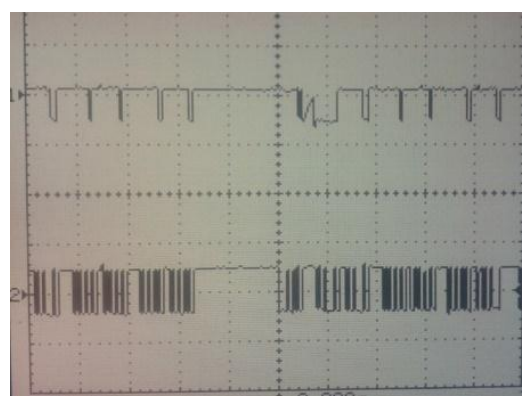

Fig. 8. DS18B20 sensor signal.

In Figure 7 shows a wave when the sensor is detected and not, the pulse sensor obtained output voltage of $2.44 \mathrm{v}$, and in Figure 8 . The results obtained from the temperature sensor ds18b20 with two different temperature sensor conditions, the first when the sensor detects a temperature of 28 degrees (first wave), and the second when the sensor detects a temperature of 34 degrees (second wave), based on the first wave of the resulting output voltage $4.41 \mathrm{v}$ and the second is $4.66 \mathrm{v}$, the measurement can be inaccurate because of the condition of the measuring instrument is not good.

\subsection{SPI pins testing}

Figure 9 shows the observed results on serial communication output waveform between the arduino and ethernet shield:

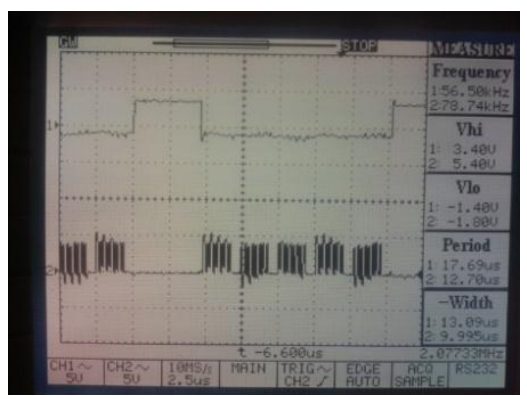

Fig. 9. Osciloscope display of pin SS and SCK signals.

Pin SS is a pin that have function to activate the slave so that data transmission can only be done if the slave is active (active low) and PIN SCK have functions as clock. To avoid communication errors, synchronization is required, Synchronization is done by using the SCK path (or called as SCLK, Serial CLOCK). Data (MISO and MOSI) will be considered valid only when SCK high state. Figure 10 shows the observed results on SS pin waves against MISO and MOSI. 


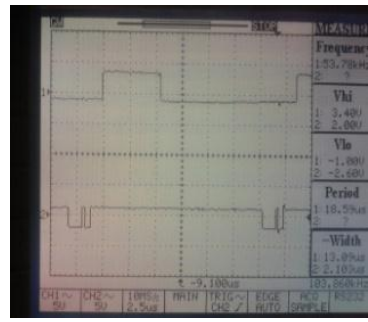

(a)

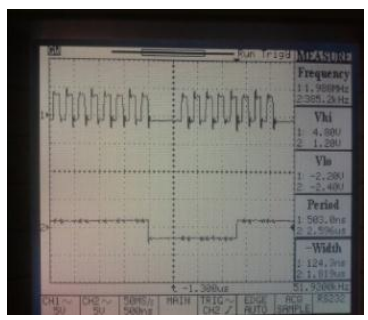

(c)

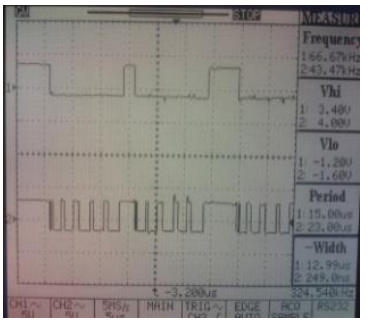

(b)

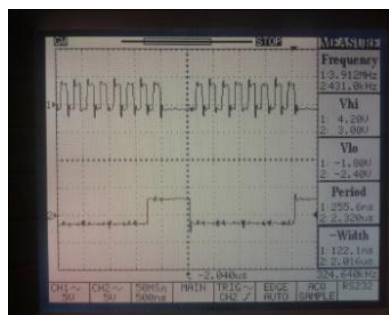

(d)

Fig. 10. (a) SS and MISO Pin, (b) SS and MOSI Pin, (c) SCK and MISO Pin, (d) SCK and MOSI Pin.

MISO (Master In Slave Out) \& MOSI (Master Out Slave In) is the data path for communication between master (programmer /downloader, USBAsp) and Slave (microcontoller IC). As the name implies, MISO is the path used to download or receive data, then MOSI is downloader path sending data to IC microcontroller.

\subsection{Overall device testing}

This test aims to determine whether the overall design is working properly or not. This test is done by assembling all parts of the device and then testing the device. Not only on assembly, in this testing described the working order of tools, ranging from hardware to the order of how to access data on the website The entire section of the device that has been assembled can be seen in Figure 11.

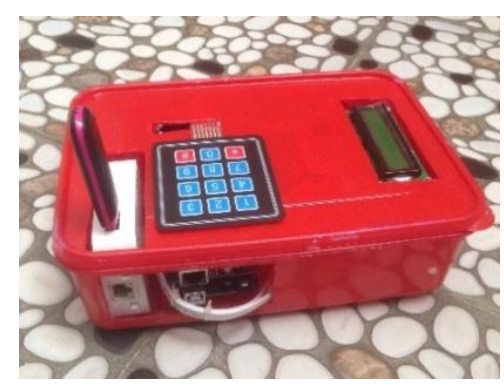

Fig. 11. Overall device.

Testing is done by following steps:

1. Type in browser:

http://heartbeattemperature.890m.com. 
2. Login form will appear. Then enter the correct name and password and then click login, then "Daftar Pasien" will appear.

3. Then add new data to the database by clicking the "Tambah Pasien" button on the "Daftar Pasien" page and then fill in the required information. Here we fill in the name as "Pasien Baru", date of birth January 4, 1995 and gender is male.

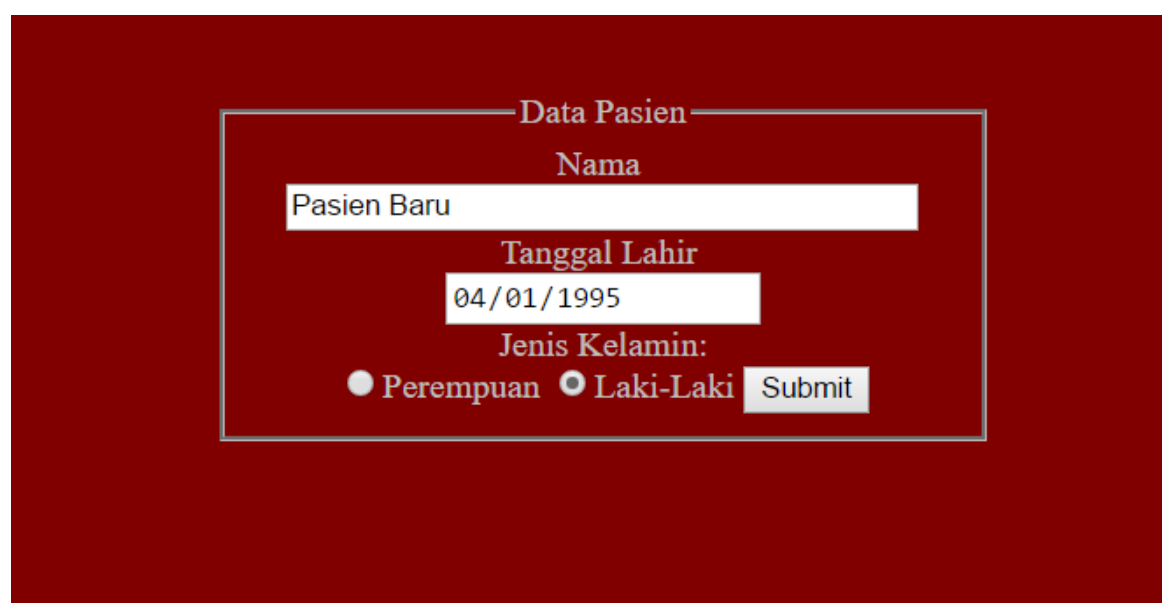

Fig. 12. Adding new data display.

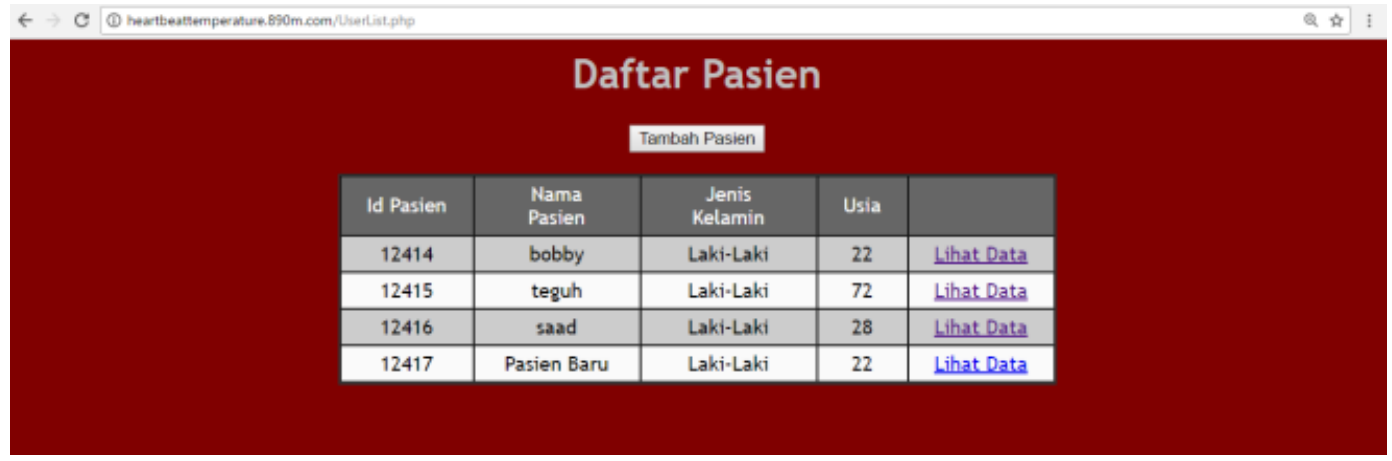

Fig. 13. New data already added.

As we can see in Figure 13, "New Patients" data has been added.

4. Measure the heart rate by using the device, enter the ID number and upload the result to the web server.

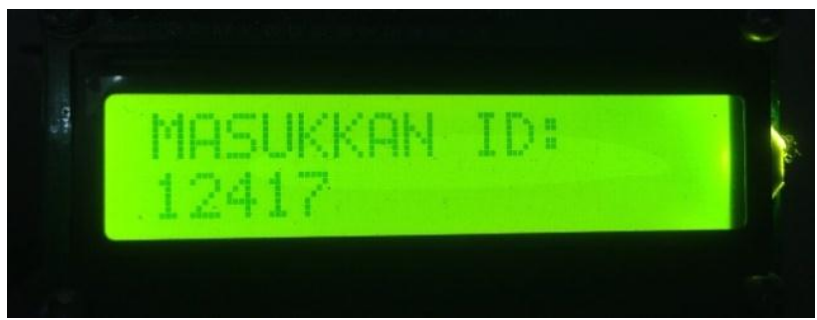

Fig. 14. New patient input ID number. 


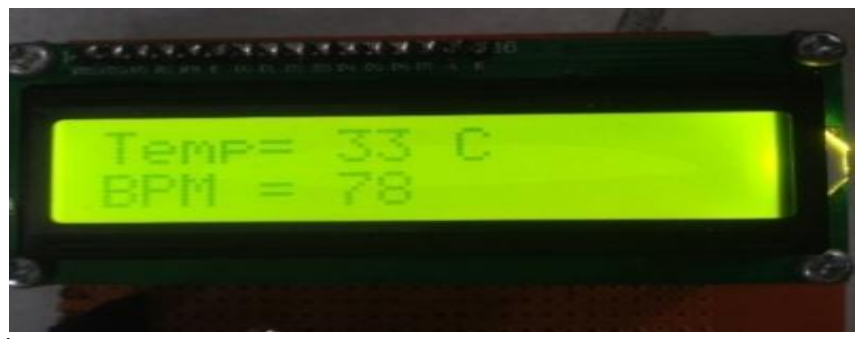

Fig. 15. New patient measures.

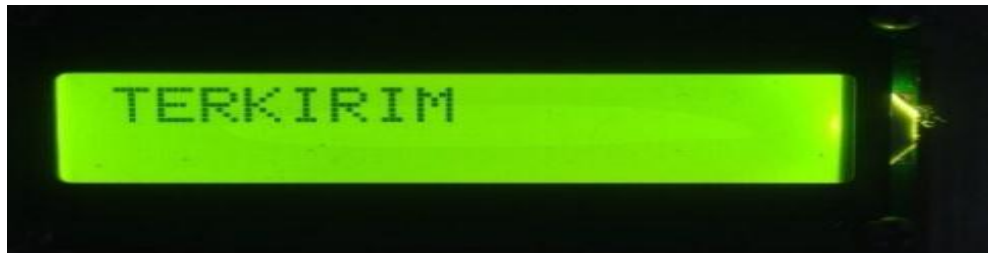

Fig. 16. Measurement result has sent to database.

5. Check whether the results have been uploaded by clicking "Lihat Data" on the "Patient List" page.

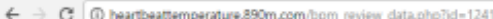

\section{DETAK JANTUNG \& TEMPERATURE}

\begin{tabular}{|c|c|c|c|}
\hline ID Pasien & $\begin{array}{c}\text { Waktu } \\
\text { Pengukuran }\end{array}$ & $\begin{array}{c}\text { Detak Jantung } \\
\text { (BPM) }\end{array}$ & Temperature \\
\hline
\end{tabular}

Fig. 17. Data before measurement.

\section{DETAK JANTUNG \& TEMPERATURE}

\begin{tabular}{|c|c|c|c|}
\hline ID Pasien & $\begin{array}{c}\text { Waktu } \\
\text { Pengukuran }\end{array}$ & $\begin{array}{c}\text { Detak Jantung } \\
\text { (BPM) }\end{array}$ & Temperature \\
\hline 12417 & $\begin{array}{c}04 \text { May } 2017 \\
19: 27\end{array}$ & 78 & 33 \\
\hline
\end{tabular}

Fig. 18. Data after measurement. 


\subsection{Testing accuracy of heartbeat counter}

The test aims to determine the accuracy value of the tool by comparing the measurement results of devices that have been made with Oxymeter Elitech Mobile Fox 1 and Smartphone Iphone 7 that supports the calculation of the human heart rate also compares the body temperature gauge with digital thermometer innate magic star. The comparison will be displayed as a percentage error by comparing different measurements $(\Delta \mathrm{bpm})$ with BPM measurements in oxymeter (oxbpm), smartphone (pbpm) as shown in the following formula:

$$
\begin{gathered}
\text { \%error }=\left(\frac{\Delta b p m}{\text { oxbpm }}\right) \times 100 \% \\
\% \text { error }=\left(\frac{\Delta b p m}{p b p m}\right) \times 100 \%
\end{gathered}
$$

The results of the test are written in the table below:

Table 1. Heartbeat rate measurment result with oxymeter.

\begin{tabular}{|l|l|l|c|c|l|}
\hline NO & Name & $\begin{array}{l}\text { Gender/ } \\
\text { Age }\end{array}$ & $\begin{array}{l}\text { BPM } \\
\text { Tool } \\
\text { Value }\end{array}$ & $\begin{array}{l}\text { BPM } \\
\text { Oxymeter } \\
\text { Value }\end{array}$ & $\begin{array}{l}\text { Error } \\
\text { Rate } \\
\mathbf{( \% )}\end{array}$ \\
\hline 1 & Bobby & Male/22 & 80 & 79 & 1.27 \\
\hline 2 & April & Female/23 & 81 & 82 & 1.22 \\
\hline 3 & Yanti & Female/50 & 76 & 76 & 0 \\
\hline 4 & Saad & Male/22 & 97 & 95 & 2.11 \\
\hline 5 & Nayla & Female/12 & 80 & 80 & 0 \\
\hline 6 & Daniel & Male/22 & 112 & 105 & 6.67 \\
\hline 7 & Cheril & Female/6 & 73 & 77 & 5.19 \\
\hline 8 & Edy & Male/58 & 80 & 77 & 3.89 \\
\hline 9 & Aji & Male/22 & 98 & 98 & 0 \\
\hline 10 & Inggri & Female/22 & 70 & 75 & 6.67 \\
\hline Average Error Rate (\%) & & & 2.702 \\
\hline
\end{tabular}

Table 1 summarizes the results of measurements to ten respondents. The results are different for each person because of the condition and age. Based on the table data, the results of comparison between heartbeat sensors and oxymeter measurements have an average error rate of $2.702 \%$. The test results of compare tools made with smartphone applications are written in the Table 2. 
Table 2. Heartbeat rate measurement result with smartphone.

\begin{tabular}{|l|l|l|l|l|l|}
\hline NO & Name & $\begin{array}{l}\text { Gender/ } \\
\text { Age }\end{array}$ & $\begin{array}{l}\text { BPM } \\
\text { Tool } \\
\text { Value }\end{array}$ & $\begin{array}{l}\text { BPM } \\
\text { Smartphone } \\
\text { Value }\end{array}$ & $\begin{array}{l}\text { Error } \\
\text { Rate } \\
\mathbf{( \% )}\end{array}$ \\
\hline 1 & Bobby & Male/22 & 80 & 81 & 1.23 \\
\hline 2 & April & Female/23 & 81 & 84 & 3.57 \\
\hline 3 & Yanti & Female/50 & 76 & 76 & 0 \\
\hline 4 & Saad & Male/22 & 97 & 97 & 0 \\
\hline 5 & Nayla & Female/12 & 80 & 73 & 9.59 \\
\hline 6 & Daniel & Male/22 & 112 & 117 & 4.27 \\
\hline 7 & Cheril & Female/6 & 73 & 74 & 1.35 \\
\hline 8 & Edy & Male/58 & 80 & 80 & 0 \\
\hline 9 & Aji & Male/22 & 98 & 101 & 2.97 \\
\hline 10 & Inggri & Female/22 & 70 & 73 & 4.11 \\
\hline Average Error Rate (\%) & & & 2.709 \\
\hline
\end{tabular}

Table 2 summarizes the comparison between heartbeat sensors and smartphone measurements has an average error rate of $2.709 \%$. Several levels of error respondents is quite high because the measurement under different conditions, especially the condition of the sensor there is gross error, systematic or random error.

\subsection{Testing accuracy of temperature}

Testing aims to determine the value of the accuracy of the tool by comparing the measurement results of devices that have been made with the body temperature thermometer digital thermometer congenital magic star. The comparison will be displayed as a percentage error by comparing the different temperature measurements $(\Delta \mathrm{cel})$ with the measurement of a digital thermometer (tcel) as shown in the following formula:

$$
\% \text { error }=\left(\frac{\Delta c e l}{\text { tcel }}\right) \times 100 \%
$$

In testing tools made and compared with a digital thermometer is written in the table below: 
Table 3. Temperature measurment result of ten respondents.

\begin{tabular}{|l|l|l|c|c|c|}
\hline $\begin{array}{c}\mathbf{N} \\
\mathbf{0}\end{array}$ & \multicolumn{1}{|c|}{ Name } & $\begin{array}{c}\text { Gender/ } \\
\text { Age }\end{array}$ & $\begin{array}{c}\text { Tool Value } \\
\left({ }^{\circ} \mathbf{C}\right)\end{array}$ & $\begin{array}{c}\text { Public Termo Digital } \\
\left({ }^{\circ} \mathbf{C}\right)\end{array}$ & Error Rate (\%) \\
\hline 1 & Bobby & Male/22 & 36 & 36.6 & 1.64 \\
\hline 2 & April & Female/23 & 35 & 35.6 & 1.69 \\
\hline 3 & Yanti & Female/50 & 34 & 35.2 & 3.43 \\
\hline 4 & Saad & Male/22 & 36 & 36.6 & 1.64 \\
\hline 5 & Nayla & Female/12 & 37 & 36.3 & 3.58 \\
\hline 6 & Daniel & Male/22 & 37 & 38 & 2.63 \\
\hline 7 & Cheril & Female/6 & 36 & 36.1 & 0.28 \\
\hline 8 & Edy & Male/58 & 36 & 36.4 & 1.1 \\
\hline 9 & Aji & Male/22 & 36 & 37.4 & 3.74 \\
\hline 10 & Inggri & Female/22 & 34 & 34.7 & 2.02 \\
\hline \multicolumn{7}{|l}{ Average Error Rate (\%) } & & 2.18 \\
\hline
\end{tabular}

Table 3 summarizes the results of measurements to ten respondents. The results are different for each person because of the condition and age. Based on the table data, the result of comparison between sensor temperature and digital thermometer measurement has an average error rate of $2.18 \%$.

\subsection{Testing precision of heartbeat counter}

This test aims to determine the precision value of the tool made. In the first precision test, the test was performed for three people tested by doing 10 times with the same tool and finger location then tested for five different fingers for five times. Besides, it is also tested the precision of thermometer made on 10 people tested as much as five times the test. The precision value of each finger measurement can be obtained using the relative standard equation (RSD) is a statistical measurement that describes the distribution of data to the mean and the result is expressed as a percentage.

$$
\begin{gathered}
s=\sqrt{\frac{1}{N} \sum_{i=1}^{N}(x i-\bar{x})^{2}} \\
R S D=\frac{s}{\bar{x}} \times 100 \%
\end{gathered}
$$

Where:

$$
\begin{array}{ll}
\mathrm{S} & : \text { Standard Deviation } \\
x i & : \text { Observed value } \\
\bar{x} & : \text { Mean of observed value } \\
\mathrm{N} & : \text { size of sample } \\
\mathrm{RSD} & : \text { Relative Standard Deviation }
\end{array}
$$




\subsection{Precision for one finger}

The Table 4 summarizes the results of the test with one finger of the same but performed for 10 times:

Table 4. Result of one finger measurement.

\begin{tabular}{|c|c|c|c|}
\hline \multirow{2}{*}{ TESTING } & \multicolumn{3}{|c|}{ Heartbeat Result (BPM) } \\
\cline { 2 - 4 } & $\begin{array}{c}\text { Responden } \\
1\end{array}$ & $\begin{array}{c}\text { Responden } \\
2\end{array}$ & $\begin{array}{c}\text { Responden } \\
3\end{array}$ \\
\hline 1 & 81 & 88 & 82 \\
\hline 2 & 82 & 85 & 82 \\
\hline 3 & 78 & 87 & 84 \\
\hline 4 & 81 & 84 & 86 \\
\hline 5 & 81 & 84 & 84 \\
\hline 6 & 86 & 86 & 83 \\
\hline 7 & 82 & 90 & 83 \\
\hline 8 & 83 & 92 & 86 \\
\hline 9 & 84 & 86 & 84 \\
\hline 10 & 81 & 84 & 83 \\
\hline RSD(\%) & 2.60 & 3.14 & 1.69 \\
\hline $\begin{array}{l}\text { Average } \\
\text { RSD (\%) }\end{array}$ & 2.48 & & \\
\hline \multicolumn{4}{|l}{} \\
\hline
\end{tabular}

Table 4 shows the measurements of 3 tested people who are tested in ten times to get value of precision. The first tested person obtained RSD value $2.60 \%$, for the second 3.14 $\%$, for the third $1.69 \%$, so the average RSD yield is $2.48 \%$. In this study, the smaller the $\mathrm{RSD}$ value the better the precision value.

\subsection{Precision for all finger}

Table 5 and Table 6 shows the measurements of five joint human fingers and test in five times to get the value of precision, first tested is the thumb, index finger to little which is distinguished based on the right and left hands. In Table 5 the five right hand fingers have an average RSD value of $1.48 \%$ or an average BPM of 83.9 with a tolerance of $1.48 \%$. In Table 6 the five left hand fingers have an average RSD value of $1.80 \%$ or an average BPM of 88.44 with a tolerance of $1.80 \%$. 
Table 5. Right hand fingers measurement result.

\begin{tabular}{|l|l|l|l|l|l|l|l|}
\hline Heart Beat Result (BPM) \\
\hline Right & \multicolumn{5}{l}{ RESPONDEN } & \multirow{2}{*}{ STDEV } & RSD (\%) \\
\cline { 2 - 6 } Finger & 1 & 2 & 3 & 4 & 5 & & \\
\hline Thumb & 90 & 87 & 88 & 87 & 90 & 1.52 & 1.72 \\
\hline Index & 93 & 90 & 90 & 93 & 91 & 1.52 & 1.66 \\
\hline Middle & 88 & 87 & 84 & 88 & 85 & 1.82 & 2.10 \\
\hline Ring & 89 & 88 & 87 & 90 & 88 & 1.14 & 1.29 \\
\hline Little & 85 & 90 & 89 & 87 & 87 & 1.95 & 2.23 \\
\hline AVERAGE & \multicolumn{7}{|l}{} \\
\hline
\end{tabular}

Table 6. Left hand fingers measurement result.

\begin{tabular}{|c|c|c|c|c|c|c|c|}
\hline \multicolumn{8}{|c|}{ Heart Beat Result (BPM) } \\
\hline \multirow{2}{*}{$\begin{array}{l}\text { Left } \\
\text { Finger }\end{array}$} & \multicolumn{5}{|c|}{ RESPONDEN } & \multirow{2}{*}{ STDEV } & \multirow{2}{*}{$\operatorname{RSD}(\%)$} \\
\hline & 1 & 2 & 3 & 4 & 5 & & \\
\hline Thumb & 81 & 84 & 85 & 82 & 82 & 1.64 & 1.98 \\
\hline Index & 88 & 87 & 88 & 84 & 87 & 1.64 & 1,89 \\
\hline Middle & 84 & 84 & 84 & 85 & 84 & 0.45 & 0.53 \\
\hline Ring & 81 & 82 & 83 & 82 & 84 & 1.14 & 1.38 \\
\hline Little & 84 & 84 & 85 & 82 & 82 & 1.34 & 1.61 \\
\hline \multicolumn{6}{|c|}{ AVERAGE } & 1.24 & 1.48 \\
\hline
\end{tabular}

\subsection{Testing precision of temperature}

This test aims to determine the precision value of the tool made. Precision test is done by counting body temperature 10 respondents with each responder counted five times, as shown in Table 7.

Table 7 shows the measurements of 10 tested people who are tested five times to get the value of precision, for first to ten respondents have an average average RSD $1.77 \%$ or an average BPM of 35.56 with a tolerance of $1.77 \%$. The smaller value of RSD then too greater precision value of a tool. 
Table 7. Temperature measurement result table.

\begin{tabular}{|c|c|c|c|c|c|c|c|}
\hline \multicolumn{8}{|c|}{ Temperature Testing $\left({ }^{\circ} \mathrm{C}\right)$} \\
\hline \multirow[t]{2}{*}{ RESPONDEN } & \multicolumn{5}{|c|}{ TESTING } & \multirow{2}{*}{ STDEV } & \multirow[t]{2}{*}{ RSD (\%) } \\
\hline & 1 & 2 & 3 & 4 & 5 & & \\
\hline 1 & 36 & 36 & 36 & 35 & 36 & 0.45 & 1.25 \\
\hline 2 & 35 & 36 & 35 & 35 & 36 & 0.55 & 1.55 \\
\hline 3 & 37 & 35 & 34 & 36 & 36 & 1.14 & 3.20 \\
\hline 4 & 37 & 37 & 37 & 37 & 37 & 0.00 & 0.00 \\
\hline 5 & 36 & 36 & 35 & 36 & 36 & 0.45 & 1.25 \\
\hline 6 & 34 & 34 & 35 & 35 & 34 & 0.55 & 1.59 \\
\hline 7 & 36 & 35 & 34 & 35 & 34 & 0.84 & 2.40 \\
\hline 8 & 36 & 36 & 36 & 37 & 37 & 0.55 & 1.50 \\
\hline 9 & 35 & 34 & 34 & 37 & 36 & 1.30 & 3.70 \\
\hline 10 & 35 & 35 & 36 & 35 & 35 & 0.45 & 1.27 \\
\hline \multicolumn{6}{|c|}{ AVERAGE } & 0.63 & 1.77 \\
\hline
\end{tabular}

\section{Conclusion}

This research has succeeded in designing heart rate control device and human body temperature which result can be accessed on web page with internet. This research consists of input blocks are Pulse sensors, DS18B20 sensors and 3×4 keypad buttons, process blocks: Microcontroller, Ethernet Shield, Router and USB Modem, and output blocks: $16 \times 2 \mathrm{LCD}$ and smartphone or PC to access web pages.

The measurement did at $60 \mathrm{~s}$ time for pulse sensor and temperature sensor DS18B20. Based on the tests that have been done to all correspondents, the heartbeat rate test with the device made has an error rate of $2.702 \%$ compared to the mobile for 1 pulse oxymeter, and when compared to the measurement in the smartphone application the device is made to have an error rate of $2.709 \%$. Then on the test of human body temperature measurement, the device made has an error rate of $2.18 \%$ compared to digital thermometer that is already common or sold in the market.

Based on the tool's precision test, the test on the respondent's one point finger has an average precision value of RSD $2.48 \%$. In addition, for measurements of right and left correspondent point fingers, right hand measurements have an average precision value of RSD $1.48 \%$ and for the left hand is RSD $1.80 \%$. Then for the device precision test on the body temperature measurement has an average precisiom value of RSD $1.77 \%$. Based on the measurements of three tested people who are tested in ten times, the average RSD yield is $2.48 \%$.

\section{References}

1. D.O.L Sihombing, L. Lubis, N. Setiowati, S. Sophiana. Pengaruh suhu terhadap denyut jantung [temperature effect to heartbeat]. [Online] from https://www.scribd.com/doc/245978378/Pengaruh-Suhu-Ter hadap-Denyut-Jantung (2016). [Accessed 12 July 2017]. [In Bahasa Indonesia] 
2. A. Mandal. Penyebab stroke panas [cause of heat stroke]. [Online] from http://www.news-medical.net/health/Causes-of-heat-stroke-(Indonesian).aspx (2016). [Accessed 12 July 2017].

3. W.K. Raharja, S. Frandika. Alat pengukur jumlah detak jantung berdasarkan aliran darah ujung kiri [hearbeat measurement tool based on left blood flow]. Prosiding Seminar Ilmiah Nasional Komputer dan Sistem Intelijen (Jakarta, Indonesia 2014). KOMMIT 2014, 8:425-431(2014). [in Bahasa Indonesia]. http://ejournal.gunadarma.ac.id/index.php/kommit/article/view/1060/922

4. Jalinas, W.K. Raharja, F. Permana, Y. Rianto. Rancang bangun alat pemonitor detak jantung berbasis koneksi WIFI [Heartbeat monitoring tool's plan based on WIFI connection]. Prosiding Seminar Nasional Aplikasi Sains \& Teknologi, (Yogyakarta, Indonesia 2016). Prosiding SNAST: 275-281. [in Bahasa Indonesia]. http://journal.akprind.ac.id/index.php/snast/article/view/786 [Accessed 12 July 2017].

5. InnerBody. Human heart - diagram and anatomy of the heart. [Online] from http://www.innerbody.com/image/card01.html (2016) [Accessed 12 July 2017].

6. M. Elgendy. Current Cardiology Reviews, 8(1):14-25 (2012) [Accessed 12 July 2017].

7. Pulse Sensor. Pulse Sensor Open Hardware. [Online] from https://pulsesensor.com/pag es/open-hardware (2016). [Accessed 18 July 2017].

8. Arduino. Arduino DS18B20 Temperature Sensor. [Online] from https://www.tweaking4all.com/hardware/arduino/arduino-ds18b20-temperature-sensor (2016). [Accessed 12 July 2017].

9. Arduino. Arduino Mega 2560 REV3. [Online] from http://www.arduino.cc/en/Main/ArduinoBoardMega2560 (2016). [Accessed 18 July 2017].

10. TP-Link. Portable 3G/4G Wireless N Router TL-MR3020. [Online] from http://www.tp-

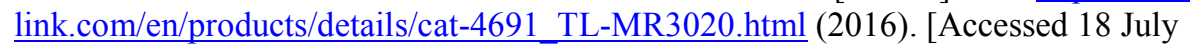
2017]. 